\title{
Probing Possibilities of Applying Productive Pedagogy to English Teaching in China*
}

\author{
Changlin Sun \\ Shandong Jianzhu University, Jinan, China
}

\begin{abstract}
Productive Pedagogy has been proved an effective teaching approach in Australia for its combination of a diversity of essential teaching aspects. It takes four dimensions into consideration, namely intellectual quality, connectedness, supportive environment and recognition of differences, which is supposed a very comprehensive understanding of the essence of teaching. Productive Pedagogy stresses a high level studying and improved learning outcomes over superficial knowledge knowing. With the help of this teaching approach, students are more likely to develop a variety of abilities such as deep learning, critical thinking, problem solving and so on. Different from Productive Pedagogy, English teaching in China still exists in grammar-translation, schools, teachers, parents and students are stopping at fragmented language learning. As a result, Chinese students are weak at thinking critically and solving real problems. How to change teaching model in China and by what way? Is it possible to apply completely this new teaching approach to China's English teaching? Productive Pedagogy is discussed in this paper for its advantages to produce students' learning outcomes. However, different countries have different culture and teaching and learning environment, when applying a new way, it needs to take the real context into account. In China, it is possibly to introduce Productive Pedagogy in private schools initially rather than public schools due to the supportive leadership, learning community, teaching and assessment philosophy in private schools. To specific, some productive activities together with Productive Pedagogy moving beyond China's current English teaching model have also been suggested.
\end{abstract}

Index Terms — productive pedagogy, problems, possibilities, suggestions, English teaching in China

\section{INTRODUCTION}

Many English teachers in China claim their teaching approaches are practical and systematic. They regard their particular techniques superior to the exclusion of the others. However, despite these claims, there is no single teaching methodology covering the needs of all English-language students (Wilhoit, 1994). On the contrary, it is believed that a variety of methodologies, if they could be skillfully combined, can complement each other and form a set of cohesive, realistic and highly motivated teaching pedagogy. The combination of varied methodologies is a practical approach suited to students' needs. This is because learning is not just for knowing superficial knowledge, rather, it should reinforce students' deep learning and higher-order thinking and improve students' problem solving ability.

Productive Pedagogy as a new approach to teaching is constructed by the Queensland School Reform Longitudinal Study (QSRLS) in Australia. Productive Pedagogy reassembles familiar classroom techniques into a workable model that focuses on high quality student learning and improved outcomes (Gore, 2002). Since China's English teaching is probing new methodologies and approaches, as a new teaching approach, is it possible to introduce Productive Pedagogy to China? In this paper the possibilities and suggestions of applying Productive Pedagogy to China's English teaching will be mainly discussed out of a general introduction and evaluation of Productive Pedagogy.

\section{A General Understanding Of Productive Pedagogy}

Productive pedagogy is about teaching behavior identified by QSRLS as being characteristics of good teaching practice (Education Queensland 2001). According to Dashwood (2004), Productive Pedagogy was taken from Newmann and Associates' authentic pedagogy, an approach to classroom teaching. With this approach, students' learning results were described by academic and social terms and a backward mapping process. Gore (2002) explains that productive pedagogy as drawing teachers' attention to what really matters is helping kids to learn. Gore argues a focus on challenging, intellectually demanding learning for all students has been neglected. It leads to a basic difference between Productive Pedagogy and other teaching methods. Besides, it stresses on a comprehensive teaching progress rather than only one aspect of teaching. More importantly, it highlights different essential aspects of classroom teaching. These essential aspects can be separated into four dimensions according to Gore (2002):

1. Intellectual quality, which stimulates students' high-level thinking and bears a problematic approach to knowledge which encourages communicating thoughts and arguments as opposed to a "give" approach. It aims to enable students

\footnotetext{
* This paper is one of the achievements of programs of Shandong Soft Science Study Program (2012RKB01185) and Shandong Education Bureau Program (J12WE01).
} 
to think deeply and develop comprehensive understandings.

2. Connectedness, which aims to help students link different aspects of school learning with connections to their past experiences and the world out of the classroom.

3. Supportive environment, where students are able to impact activities and how they are implemented. It also requires students to highly discipline themselves. It is kinds of promise to assure the classroom supports learning.

4. Recognition of differences, which takes non-dominant groups into consideration and aims at recognizing group differences and identities.

\section{Reasons to Introduce Productive Pedagogy to English Teaching in China}

Since China opened her door to the international world, English played an important role in almost every field in China including business trading, science and technology, intercultural communication and so on. English proficiency was more and more stressed by different people from different enterprises. It has no doubt to bring a blossom in English teaching and learning. From kindergarten to university, from unique family to big companies, people are harboring a strong passion to learn English. English lessons are compulsory from junior high school till Phd's level. More importantly, English score has been used as a standard to measure students' ability to pass school's entrance test. But having a general overlook of the current English teaching we can see English teaching model in China still stops at grammar-oriented, while the teaching attention focuses on the analysis of grammatical points, the expansion of vocabulary, the translation of sentences and the understanding of sentence meaning. Teachers rarely teach students how to think critically and deeply and how to connect what they have learned to the real world. As a result, English teaching and learning stands at the surface level, leading a fragmented knowledge learning to most students, and connectedness between teaching and the real life is broken up. Even worse, teaching benefits higher level students more than lower level students, which leads to a bigger gap between "strong" students and "weak" students.

Compared with China's English teaching model, Productive Pedagogy provides a more holistic perspective. It not only benefits students at deep knowledge learning, deep understanding and problematic knowledge learning, but also helps students make connections between in and out of school learning, provides an effective environment where students harbors high expectation and are willing to learn and supports students from non-dominant groups to learn.

School leaders and teachers would not like to take risks to develop students' higher-order thinking, deep learning and problem solving ability. This is particularly true in public schools. In these schools, teachers' major task is to enable students to pass exams, and they are under less pressure to help students improve comprehensive learning abilities. Consequently, students' learning cannot be broadened and deepened, the unitary teaching belief and pedagogy have limited the development of students' learning ability.

\section{Possibilities to Introduce Productive Pedagogy to English Teaching In China}

Because of the problems in China's current English teaching, it is necessary to seek for new approaches for English teaching in China. Productive Pedagogy, rooted in authentic pedagogy, but expanded to advance students' academic and social achievements is one of the possible approaching. However, the introduction of Productive Pedagogy must take China's real context into its account, and this introduction should be entered into primary and second schools in China step by step. After all, the current teaching model has existed for a relatively long period, the introduction of Productive Pedagogy needs time and hard work.

In China, since it is not easy to change school's culture and policy, in particular in public schools, is it possible to introduce Productive Pedagogy to private schools initially? It's possibly because private schools have flexible management systems which will facilitate the introduction of Productive Pedagogy. In addition, from school leaders to teachers, they are easy to share common beliefs consistent with the school's goal. Furthermore, they are under pressure to improve teaching quality to attract as many students as they can to help the school survive. Specifically, supportive leadership, a professional learning community, changing teaching and assessing philosophy provide possibilities for private schools to accept Productive Pedagogy.

\section{Supportive leadership in private schools}

Leadership is considered an important factor to support a school's development. From Blackmore (1999) and Lingard and Douglas (1999), leadership creates an emotional economy within the school that is supportive of teachers and students and encourages innovation and risk taking. Teaching and learning are attached the greatest importance within the organization of the school. Leaders who act as "keepers of the vision" and who are able to identify and reward actions that further the vision and mission of the school are crucial for organizational innovation (Louis, Marks, \& Kurse, 1996, p.757). They act as a critical source of information on how to deviate from the existing situation (Louis \& Murphy, 1994). As school leaders work toward building new cultures, they can create coherence and unity and establish a sense of internal quality for innovative efforts within the community (Vandenberghe \& Staessens, 1991).

School's different features talks louder in private schools than in public schools. Public schools usually have existed for a long period, which makes themselves difficult to have some changes, while some private schools are quite new and the organizational structure is relatively flexible, it is easier for them to adopt more advanced philosophies to develop well. Moreover, private schools' management is more a "bottom-up" than a "top-down", which means teachers 
have much freedom to select what they want to do. In order to provide more effective teaching, most leaders in private schools hold a positive attitude toward education innovation. They support new methods, encourage effective actions and prepare well to meet changes and challenges. The culture in private schools is more democratic and focusing on teaching. Principals will consider more about how to improve teaching quality and enhance students' learning outcomes instead of binding themselves to lots of meetings. Hence, the principal and teachers will find it more possible to share ideas and understandings consistent with the school's goals. This supportive leadership environment will facilitate the introduction of Productive Pedagogy.

\section{A learning community in private schools}

According to Louis, Kruse and Marks (1996), a teacher professional learning community stresses reflective collaboration among teachers around the relationship between their pedagogy and student learning outcomes. A learning community is an effective way for teachers to learn from each other, share experiences with each other and improve teaching quality together (Lingard, 2000, p.24). The realistic situation in China's teaching shows that private school teachers have built up a more efficient learning community than public schools teachers, which helps private schools teachers benefiting from this community by improving teaching strategies and enriching productive practices.

\section{Teaching and assessment philosophy is changing in private schools}

Searching for high quality teaching and effective learning promotes leaders and teachers in private schools to rethink that teaching and assessments are not just a means of grading. Teaching and assessment should be used to help students learn. Teachers should use examinations, assignments, observations and questionnaires to facilitate students understanding of their progress in learning and to improve the quality of teaching programs, services and facilities. Bain (2004) points out that assessment stresses learning rather than performance. The teacher should keep in mind that what kind of intellectual and individual development does a student achieve but not if the student behaves properly in class and if he or she completes assignments timely.

In some private schools, teachers are trying student-centered teaching methods. They have placed students at the centre of learning and made them responsible for their own learning. In this way, students will be provided the necessary information and skills to take full advantage of learning. In this learning-centered environment, students are not just fed knowledge by teachers, on the contrary, students are provided the necessary information and skills to take full advantage of learning. They are expected to have discussions, do group work, and achieve authentic learning. Under these circumstances, scores that reflects rote learning or surface learning of concepts are not important. Instead, how to use different forms of assessment, and create connections between the outside world, the community, and the classroom are essential to have a positive impact on students (Bain, 2004). This transformation from teacher-centered to student-centered and the new reorganization of assessment also help Productive Pedagogy be introduced.

\section{Suggestions to Apply Productive Pedagogy to English Teaching in China}

Theoretically, Productive Pedagogy is a comprehensive understanding of teaching and learning philosophy. Though it comes from authentic pedagogy, it is beyond it and expands teaching practice to enhance students' social outcomes. Practically, when Productive Pedagogy is applied to real class teaching in China, it needs to be critically adapted and changed. What applies to one country may not fit for another country very well. For instance, Productive Pedagogy emphasizes recognition of cultural differences and group identity, and in comparison with cultural diversity in Australia, most Chinese students come from the same cultural background and hold similar identities. Rather than valuing diverse cultures, respecting different cultural identities and treating minority students as the same as mainstream students, English teaching in China appeals more activities to enhance students' higher-order thinking, deep thinking, collaborative learning and problem solving. So, Productive Pedagogy must be localized to satisfy the needs of Chinese students.

How to critically apply Productive Pedagogy aligning with Productive activities to China's English teaching moving beyond its current grammar-translation model? Some possible suggestions are provided for reference.

- Teach complex thinking

- Teach from authentic conversation

- Provide supporting class atmosphere to all students

- Develop language competence across the problem-based curriculum

- Connect school to students' real life

Taken together, these activities describe how to organize student to participate in a variety of activities and to guide their learning in meaningful ways. Some activities intend to improve students' intellectual quality and enhance their ability to integrate knowledge, to connect knowledge to the real world, and to solve real problems. For instance, teaching complex thinking, developing language competence across curriculum, connecting school to students' real life, and teaching from authentic conversation. Some activities provide a supporting environment for student to receive teacher's attention and interaction. Every individual student is respected and included in the classroom learning no matter if they are high-level students or low-level students. In another word, supporting class atmosphere is equal to all students. All students are expected to learn in and out class by their teachers, likewise, they themselves harbor the same expectation, and most importantly, teachers can provide instruction to them to learn by implementing class activities. 
When evaluating theses innovative activities, it is not difficult to identify that these activities have gone beyond the idea that English teaching and learning is for exam purposes, for mastery of grammar rules and memorizing vocabulary, they transfer teaching philosophy from teacher-centered, teacher "given" and student "taken" style to student-centered and students and the teacher interacting and collaborating together. By using these productive activities, students' learning motivation, interest, creativity and problem solving abilities will be improved. Students will not be the learning machines any more, rather, they will control themselves in the learning process and act as the master of learning activities.

\section{Teach complex thinking}

According to Ramsden (2003), learning should be about changing the ways in which learners understand, or experience, or conceptualize the world around them. Learning should help students to widen their insights, broaden their knowledge, deepen their comprehension of the world. Specifically, the teacher can present student performance standards, design challenging tasks which enhance student understanding from superficial level to deep level, assist students to settle problems by combining their knowledge with real-life experience, and provide clear, direct feedback about how student performance compares with the standards (Dalton, 1998). An example of this is as follows:

\begin{tabular}{|l|l|}
\hline Activity one & Learning cultural knowledge through learning a festival \\
\hline \multirow{5}{*}{ Description } & $\begin{array}{l}\text { The teacher designs open-ended questions aimed to enable students to learn culture, } \\
\text { history, custom, and religious knowledge through learning a festival. Students read } \\
\text { books, magazines, or surf on the Internet to collect festival information in different } \\
\text { countries. To demonstrate more complex understandings, students classify different } \\
\text { types of festivals, make words or photographic illustrations of their findings, and } \\
\text { compare differences and similarities of festivals. Furthermore, students summarize the } \\
\text { general cultural characteristic of a country through analyzing information they collect. } \\
\text { By having students collect, sort, and analyze the information, they complete open-ended } \\
\text { questions from a cultural, historical and religious perspective. }\end{array}$ \\
\hline \multirow{5}{*}{ Effect } & $\begin{array}{l}\text { Students are challenged to a high level's learning. They are required not only to do } \\
\text { surface learning, such as looking for information, but more importantly to go up to a } \\
\text { higher level of learning. Students' learning is deepened, insight is broadened, and } \\
\text { intellectual abilities are improved. The teacher also expects students' deep learning by } \\
\text { giving comment on how their performance compares to the standard. The benefits exist } \\
\text { in that students not only learn clearly standards, but they obtain teacher's guidance. }\end{array}$ \\
\hline
\end{tabular}

\section{Teach from authentic conversation}

Dalton (1998) reviews authentic conversation offering chances to teachers to provide necessary and helpful assistance. When conducting learning from individual experience to text analysis, it is possible for students to make clear about the text's complex meanings. When dealing with subjective matters, students are expected to understand content deeply and to develop the ability to involve themselves in conversation about problem solving or probing the related issues. The teacher knows clearly if every student get an understanding (e.g., Are we clear?), provides opportunities for students to explain their reason (e.g., How do you know?), and encourages students to negotiate with each other (e.g., Do we agree?). disagree?). An example of this is as follows: 


\begin{tabular}{|c|c|}
\hline Activity & alking about old people and the aging process \\
\hline Description & $\begin{array}{l}\text { The teacher and students have a conversation about their experience of old people. The teacher asks } \\
\text { students' feeling about old people, according to students' answers, the teacher ask s other questions such as } \\
\text { listing reasons, comparison and summary. The teacher intends to elicit students' deep thinking. } \\
\text { Teacher: How do you feel about old people? } \\
\text { Student A: I like old people, and my grandpa is getting older. } \\
\text { Teacher: How do you know people getting old? Or what signs do you think when your grandpa is getting } \\
\text { older? } \\
\text { Student A: He gets gray hair, and his face gets wrinkled, and he cannot hear so good. } \\
\text { Teacher: See, body differences such as graying hair, wrinkle face reveal one's physical changes. But are } \\
\text { physical changes the only sign of getting old? } \\
\text { Student B: No, I don't think so, my grandpa isn't like that. He always goes to Gym. } \\
\text { Teacher: Alight, although your grandpa get old, he is pretty active, isn't he? How old is your grandfather? } \\
\text { Student B: He is } 80 \text {. } \\
\text { Teacher: Well, since your grandfather is } 80 \text {, why don't you think of him as an elderly man? } \\
\text { Student B: Because he likes sports and he's quite active. } \\
\text { Teacher: Then what do you think to act young? } \\
\text { Student B: One may like sports and fashion, he is interested in new things and he doesn't always talk } \\
\text { about the past things. } \\
\text { Teacher: What might keep an older person healthy and active? } \\
\text { Student B: No junk food, eat fresh vegetables, fruit, and drink water. Live happily and like sports and } \\
\text { traveling. } \\
\text { Teacher: In brief, in order to keep one healthy and active, he or she should have a good... } \\
\text { Student: Hobby. }\end{array}$ \\
\hline Effect & $\begin{array}{l}\text { The instructional conversation enables students to understand the central topic, characters, and events they } \\
\text { are learning. The teacher's goal of assessing students' experience with elderly people is realized by } \\
\text { questioning students constantly in the progress of conversation and helping them think more about aging. } \\
\text { The teacher's responses and comments advance the instructional goals, and elicits and encourages } \\
\text { students' deep thinking. }\end{array}$ \\
\hline
\end{tabular}

\section{Provide supporting atmosphere to all students}

The teacher explicitly conveys high expectations for all students. The teacher encourages students to take risks and master challenging academic work. The teacher designs classroom activities which require students to work together to fulfill the goal. The teacher deliberately mixes high-level students with low-level students in the groups, and encourages their cooperation and sharing opinions with each other. An example of this is as follows:

\begin{tabular}{|l|l|}
\hline Activity & Group role playing \\
\hline Description & $\begin{array}{l}\text { The teacher designs group role-playing activity for students. Each group is asked to prepare an English } \\
\text { playing and assess each other after the playing. Students in each group collaborate to organize what they } \\
\text { will say and how they will perform. Students with more English skills and proficiency are expected to } \\
\text { lead the group, and students with less skills and proficiency also are expected to give their valuable } \\
\text { opinions and take responsibilities for their roles. After each group's playing, students in other groups } \\
\text { will make comments on the work and give suggestions for improvement. }\end{array}$ \\
\hline $\begin{array}{l}\text { By implementing group role-playing, high English level students and low level students work together } \\
\text { toward a common goal and share experiences and understandings in the activity. Cooperative learning } \\
\text { helps low level students increase their academic achievement, motivation and self-esteem; meanwhile, it } \\
\text { strengthens high-level students to take more responsibilities in a group work. In addition, students are } \\
\text { encouraged to take risks to provide comments that could help improve their own work. }\end{array}$ \\
\hline
\end{tabular}

\section{Develop language competence across the problem-based curriculum}

The teacher presents students with real or practical problems and encourages them to solve them. Problems are defined as having no single correct solution, requiring the construction of knowledge by the students (The State of Queensland Department of Education, 2002). An example of this is as follows:

\begin{tabular}{|l|l|}
\hline Activity & Finding solutions \\
\hline \multirow{5}{*}{ Description } & $\begin{array}{l}\text { The teacher was working with the class on a unit about traveling. The teacher asked the students to } \\
\text { discuss the unit and prepared for a discussion about a real traveling. The discussion could base on the } \\
\text { personal experience or what the student had known from TV, magazines and books etc. The discussion } \\
\text { was towards what work would be done before the traveling, what problems might be met and how the } \\
\text { problems might be solved. After the general questions were answered, the discussion was directed by } \\
\text { the teacher to expand to wider aspects. Students were not limited to specific questions; furthermore, } \\
\text { they were elicited to broaden their insights into social and economic aspects. For instance, from } \\
\text { traveling problems to lead to the transportation problem, the pollution problem, the criminal problem } \\
\text { and the economic problem etc. The students argued why these problems related to traveling problems, } \\
\text { gave suggestions of these problems and explained their reasons. }\end{array}$ \\
\hline Effect & $\begin{array}{l}\text { Based on problem-based curriculum, students will find it easier to integrate their prior knowledge to } \\
\text { new situations. Meanwhile, teachers' instruction is important in problem-solving activities. By linking } \\
\text { real life to class teaching or creating interactive contexts, students' abilities of analyzing problems and } \\
\text { solving real life problems will be reinforced. }\end{array}$ \\
\hline
\end{tabular}

\section{Connect school to students' real life}

Real life starts from home, school, community, society and it is about what one has already known and being familiar 
with. To connect school education to student's real life, the teacher is able to design instructional activities that are meaningful to students and assist students to connect and apply what they have learned to their real life. Students are expected to solve real problems by integrating their learning and their own experience. The teacher organizes various activities to include students' preferences, from collective and cooperative to individual and competitive (Dalton, 1998). An example of this is as follows:

\begin{tabular}{|l|l|}
\hline Activity & Preparing a Christmas Party \\
\hline \multirow{5}{*}{ Description } & The teacher talks with students about how to prepare a Christmas Party. The teacher raises requirements \\
& such as creative, interesting, and fancy. Students start to design Christmas Party activities. \\
& Teacher: What will you do in the party Ming? \\
& Ming: I think I will sing a song. I really like the song in cartoon movies. \\
& Teacher: Good. How about you, Hua? \\
& Teacher: Excellent. What will you guys do? \\
& $\begin{array}{l}\text { Ping and Yang and Lin: Could we play a drama? We had taken drama lessons when we were in } \\
\text { Kindergarten, we want to play a short drama. } \\
\text { Teacher: What a nice idea. Do you have a favorite topic? } \\
\text { Ping and Yang and Lin: Mm, we are planning a topic about how to protect lawns in our school. We had } \\
\text { very nice lawns before, but after they were trampled time and time again, they were not beautiful any } \\
\text { more, and nearly broke. We want to evoke people's attention to protect lawns by playing this drama. } \\
\text { Teacher: Wonderful, you are touching the real life problems. You are using what you have learned to } \\
\text { relate to your life and intend to solve real problems. I'd like other students to think about this issue as } \\
\text { well, and write a letter to the whole school to help Ping and Yang and Lin realize their desire. }\end{array}$ \\
\hline $\begin{array}{l}\text { This activity involves the contexts external to school where student learning is situated. Students apply } \\
\text { what they have learned from their family, movies, books, and communities to class activities. Students } \\
\text { might confront an actual issue or problem, such as write a letter to protect the school environment. This } \\
\text { high level of connectedness to students'life can help students improve their problem-solving abilities. }\end{array}$ \\
\hline
\end{tabular}

\section{CONCLUSION}

Productive Pedagogy takes all students' academic and social success into its account. Students' success relies greatly on teachers' purposive intention and practical activities, regardless of the background, identities as well as student diversities. (August \& Hakuta, 1996; Milk, 1990). In other words, teachers' competence overweighs the other elements in helping a great range of students accomplish the goal of improved achievement (Darling-Hammond, 1997). Productive Pedagogy is an effective teaching model, the introduction of Productive Pedagogy to China needs it to be integrated with the real contexts. It will be more possible to introduce it to private schools initially. The Productive Pedagogy offers guidance for teaching that aims to produce complex learning in classrooms. Meanwhile, it raises higher requirements for teachers and challenges the current teaching model in China. With the increasing development of China, the introduction of Productive Pedagogy to China's English teaching will be the trend, still it needs strong leadership support, individual teacher's efforts and most importantly, the setting up of a professional learning community to enhance cooperation with each other. Now that Productive Pedagogy has been proved an effective teaching approach in improving students' learning outcome, it is worthwhile to try it into China's English class no matter what efforts and hard work will be paid.

\section{REFERENCES}

[1] August, D., \& Hakuta, K. (1997). Improving schooling for language-minority children: A research agenda. Washington, DC: National Academy Press.

[2] Bain, K. (2004). What the best college teachers do? London: Harvard University Press.

[3] Blackmore, J. (1999). Troubling women feminism, leadership and educational change. London: Open University Press, Buckingham.

[4] Dalton, S. (1998). Pedagogy matters: Standards for effective teaching practice. Research Report 4. http://www.acrnetwork.org/teachers/documents/rr4.doc (accessed 04/11/2007).

[5] Darling-Hammond, L. (1997). Doing what matters most: Investing in quality teaching. New York: The National Commission on Teaching \& America's Future.

[6] Dashwood, A. (2004). Talk and Productive Pedagogy in languages education. BABEL, Volume 39, Number 1, Winter 2004.

[7] Gore, J. (2002). Productive Pedagogy. https://www.det.nsw.edu.au/inform/yr2002/mar/pedagogy.htm (accessed 29/8/2009).

[8] Lingard, B. and Douglas, P. (1999). Men engaging feminisms: Profeminism, backlashes and schooling. London: Open University Press, Buckingham.

[9] Lingard, B. (2000). Aligning the message systems. Independent Education, October 2000, 24-26.

[10] Louis, K. S., \& Murphy, J. (1994). The evolving role of the principals and some concluding thoughts. In J. Murphy \& K. S. Louis (Eds), Reshaping the principalship: Insights from transformational reform efforts. Newbury Park, CA: Corwin Press, 265-281.

[11] Louis, K., Marks, H., \& Kurse, S. (1996). Teachers' professional community in restructuring schools. American Educational Research Journal, Winter 1996, 33 (4), 757-798.

[12] Milk, R. (1990). Preparing teachers for effective bilingual instruction. In M. McGroarty \& C. Faltis (Eds.), Languages in school and society. New York: Mouton de Gruyter, 335-360. 
[13] Ramsden, P. (2003). Learning and teaching in higher education (2nd edn). London: Routledge Falmer.

[14] The State of Queensland Department of Education. (2002). A guide to Productive Pedagogy classroom reflection manual. http://education.qld.gov.au/public_media/reports/curriculum-framework/productive-pedagogy/ (accessed 24/2/2012).

[15] Vandenberghe, R., \& Staessens, K. (1991). Vision as a core component of school culture. Paper presented at the annual meeting of the American Educational Research Association, Chicago, 1-39.

[16] Wilhoit, D. (1994). Enhancing oral skills: A practical and systematic approach. English Teaching Forum, October 1994, 32-36.

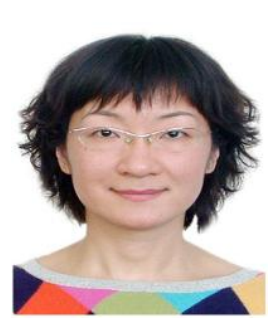

Changlin Sun was born in Jinan, China in 1970. She received her Master's degree in educational study from The University of Queensland, Australia in 2005.

She is currently a lecturer in the School of Foreign Languages of Shandong Jianzhu University in Jinan. Her research interests include TESOL, cross-cultural comparative study, and American literature. 